\title{
ANALISIS PERATURAN KEPALA BADAN PERTANAHAN NASIONAL RI NO 4 TAHUN 2010 TENTANG TATA CARA PENERTIBAN TANAH TERLANTAR (STUDI KASUS EKS. PABRIK ES DAN GUDANG KOPI DI KELURAHAN BAJAK)
}

\author{
Hendi Sastra Putra \\ Fakultas Hukum Universitas Muhammadiyah Bengkulu \\ Jalan Adam Malik Pagar Dewa Kota Bengkulu \\ Pos-el: hendi@umb.ac.id
}

\begin{abstract}
Neglected land is land that has received rights from the state in the form of property rights, land use rights, building rights, usage rights and administrative rights or the basis for the control of land that is not cultivated, not used or not used according to the circumstances or nature and nature the purpose of granting rights or the basis of their control. Problem formulation What is the role of the Bengkulu City Bureau in controlling abandoned land in the former ice cream factory and coffee store in Bajak Village? Empirical legal research is a legal research method that uses empirical facts derived from human behavior, both verbal behavior from interviews and real behavior that is performed through direct observation. Primary data is data that comes directly from the field and is based on respondents and informants. Secondary data This data comes from literature books, laws and regulations, surfing the Internet and other documents. Determination of the abandoned country in accordance with Article 19 paragraph 1, the percentage of the abandoned land area is divided into the following groups: (a) 100 percent distributed, (b) more than 25 percent to less than 100 percent displaced,, and (d) distributed less than or equal to 25 percent. Sanctions pursuant to Article 23 paragraph 1 must be cleared of land that has been designated as abandoned land within a period of 1 (one) month after the decision on the determination of the abandoned land has been made by the former rights holder of the items located thereon. (2) If the former right holder does not fulfill the obligations mentioned in paragraph 1 , the objects on it no longer belong to him and are controlled directly by the state.
\end{abstract}

Keywords: Neglected land; Rights holders; penalty

\begin{abstract}
Abstrak: Tanah terlantar adalah tanah yang sudah diberikan hak oleh negara berupa Hak Milik, Hak Guna Usaha, Hak Guna Bangunan, Hak Pakai, dan Hak Pengelolaan, atau dasar penguasaan atas tanah yang tidak diusahakan, tidak dipergunakan, atau tidak dimanfaatkan sesuai dengan keadaannya atau sifat dan tujuan pemberian hak atau dasar penguasaannya. Rumusan masalah Bagaimana peranan kantor pertanahan Kota Bengkulu dalam melakukan penertiban tanah terlantar di bekas Pabrik Es dan Gudang Kopi di Kelurahan Bajak ? Penelitian Hukum Empiris adalah suatu metode penelitian hukum yang menggunakan fakta-fakta empiris yang diambil dari perilaku manusia, baik perilaku verbal yang didapat dari wawancara maupun perilaku nyata yang dilakukan melalui pengamatan langsung. Data primer merupakan data yang diperoleh secara langsung dari lapangan berdasarkan dari responden dan narasumber. Data sekunder Data-data tersebut diperoleh dari bukubuku kepustakaan, peraturan perundang-undangan, browsing internet, dan dokumen-dokumen lainnya. Penetapan Tanah Terlantar sebagaimana dimaksud dalam Pasal 19 ayat (1), persentase luas tanah yang diterlantarkan dikelompokan menjadi : (a) 100 persen terlantar, (b) lebih dari 25 persen sampai dengan kurang dari 100 persen terlantar, dan (c) kurang dari atau sama dengan 25 persen terlantar. Untuk sanksi sesuai dengan pasal 23 (1) Tanah yang telah ditetapkan sebagai tanah terlantar, dalam jangka waktu paling lama 1 (satu) bulan sejak ditetapkannya keputusan penetapan tanah terlantar, wajib dikosongkan oleh bekas Pemegang Hak atas benda-benda di atasnya dengan beban biaya yang bersangkutan. (2) Apabila bekas Pemegang Hak tidak memenuhi kewajiban sebagaimana dimaksud pada ayat (1), maka benda-benda di atasnya tidak lagi menjadi miliknya dan dikuasai langsung oleh Negara.
\end{abstract}

Kata kunci: Tanah terlantar; Pemegang Hak; sanksi 


\section{Pendahuluan}

Tanah adalah lapisan permukaan bumi yang secara fisik berfungsi sebagai tempat tumbuh \& berkembangnya perakaran penopang tegak tumbuhnya tanaman dan menyuplai kebutuhan air dan udara.

Tanah menurut Kamus Besar Bahasa Indonesia adalah permukaan bumi atau lapisan bumi yang di atas sekali; keadaan bumi di suatu tempat, permukaan bumi yang diberi batas, daratan; permukaan bumi yang terbatas yang ditempati suatu bangsa yang diperintah suatu negara atau menjadi daerah negara; negeri; negara.

Hak-hak aas tanah dalam Undangundang Pokok Agraria No 5 tahun 1960 yaitu :

1. Hak Milik

2. Hak Guna Usaha

3. Hak Guna Bangunan

4. Hak Pakai

5. Hak Gadai

6. Hak Usaha Bagi Hasil

7. Hak Menumpang

8. Hak Sewa, dan lain lain.

Hak atas tanah yang dapat digunakan oleh investor untuk kegiatan investasi yang tertuang dalam pasal 22 undang-undang No 25 tahun 2007 tentang penanaman modal adalah :

1. Hak Guna Usaha

2. Hak Guna Bangunan

3. Hak Pakai

Pengertian hak milik menurut Pasal 20 ayat (1) UUPA adalah : hak turun-temurun, terkuat dan terpenuh yang dapat dipunyai orang atas tanah. Dalam penggunaan hak milik atas tanah tetapu harus memperhatikan fungsi sosial tanah yang tercantum dalam Pasal 6 UUPA "semua hak atas tanah mempunyai Fungsi sosial”.

Dalam kehidupan masyarakat tanah memegang peran yang sangat penting, untuk itu memerlukan penanganan yang serius dan professional. Dengan meningkatnya pembangunan disegala bidang, baik pertanian pemukiman perindustrian maka kebutuhan akan tanah tanah semakin meningkat pula. Dengan meningkatnya kebutuhan akan tanah semakin meningkat pulalah masalahmasalah yang ditimbulkan oleh tanah yang harus ditangani dengan segera ${ }^{1}$.

Salah satu masalah yang perlu ditangani dengan segera adalah masalah tanah terlantar, karena masalah ini sangat rumit sekali jika melihat adanya estalasi dari harga-harga tanah memuat masalah untuk dinyatakan tanah menjadi terlantar. Terlantar dalam arti tanah tersebut tidak dimanfaatkan secara optimal oleh pemegang hak ${ }^{2}$.

kewajiban yang melekat pada pemegang hak atas tanah, yaitu yang bersifat umum

1 Hendi Sastra Putra And Pareke. J.T, Peranan Pemerintah Kabupaten Bengkulu Utara Dalam Penertiban Tanah Terlantar Hak Guna Usaha, Ed. By Mikho Ardinata, Hukum Agraria (Jakarta: Zara Abadi, 2020).

${ }^{2}$ Hendi Sastra Putra And Pareke. J.T,.. 
dan khusus. Kewajiban umum dari pemegang hak atas tanah terkait dengan adanya fungsi sosial dari hak atas tanah (perhatikan ketentuan Pasal 6 UUPA). Pemegang hak atas tanah juga memiliki kewajiban untuk memelihara tanahnya (perhatikan Pasal 15 UUPA),

Kewajiban lainnya dari pemegang hak atas tanah yaitu untuk mengerjakan atau mengusahakan sendiri secara aktif tanah yang dimilikinya, namun kewajiban ini khusus mengenai tanah pertanian. Selain itu, kewajiban-kewajiban yang bersifat khusus dicantumkan dalam surat keputusan pemberian haknya atau dalam surat perjanjian, serta dalam peraturan perundang-undangan yang berlaku.

Pasal 15 UUPA berbunyi : Memelihara tanah, termasuk menambah kesuburannya serta mencegah kerusakannya adalah kewajiban tiap-tiap orang, badan hukum atau instansi yang mempunyai hubungan hukum dengan tanah itu, dengan memperhatikan pihak yang ekonomis lemah.

salah satu permasalahan yang terjadi di Indonesia ini adalah terus bertambah banyaknya masalah mengenai tanah terlantar, yang tanah tersebut tidak dipergunakan sebagaimana mestinya yang sudah didedikasikan kepada perorangan ataupun badan hukum. Tanah terlantar di Indonesia kini semakin banyak, karena pada dasarnya banyak pemilik tanah yang kurang mengerti hukum mengenai pertanahan dan juga akan pendayagunaan tanahnya. Dan disini pemerintah pada dasarnya akan mengambil alih tanah-tanah yang sengaja diterlantarkan oleh pemiliknya dan/atau pemegang haknya untuk kembali diberikan pada masyarakat yang lain ${ }^{3}$.

Dalam Peraturan Kepala BPN RI No. 4 Tahun 2010, tanah yang diindikasikan terlantar dan tanah terlantar. Pasal 1 Angka 5 Tanah yang diindikasi terlantar adalah tanah yang diduga tidak diusahakan, tidak dipergunakan, atau tidak dimanfaatkan sesuai dengan keadaan atau sifat dan tujuan pemberian hak atau dasar penguasaannya yang belum dilakukan identifikasi dan penelitian. Sedangkan Pasal 1 Angka 6 mengenai tanah terlantar adalah tanah yang sudah diberikan hak oleh negara berupa Hak Milik, Hak Guna Usaha, Hak Guna Bangunan, Hak Pakai, dan Hak Pengelolaan, atau dasar penguasaan atas tanah yang tidak diusahakan, tidak dipergunakan, atau tidak dimanfaatkan sesuai dengan keadaannya atau sifat dan tujuan pemberian hak atau dasar penguasaannya.

Pasal 1 angka 5 Peraturan Pemerintah Republik Indonesia No 11 Tahun 2010

3 Lianton Vicco Yunior, 'Wewenang Pemerintah Dalam Penentuan Kriteria Tanah Terlantar', Jurist-Diction, 2.6 (2019), 2175-98. 
Tentang Penertiban Dan Pendayagunan

Tanah Terlantar, memberika pengertian mengenai tanah terlantar. Tanah terlantar adalah tanah yang diterlantarkan oleh pemegang hak atas tanah, pemegang Hak Pengelolaan atau pihak yang telah memperoleh dasar penguasaan atas tanah tetapi belum memperoleh hak atas tanah sesuai ketentuan peraturan perundangundangan yang berlaku.

Pasal 3 Peraturan Pemerintah Republik Indonesia No 11 Tahun 2010 Tentang Penertiban Dan Pendayagunan Tanah Terlantar yang berbunyi : Tanah Hak Milik, Hak Guna Usaha, Hak Guna Bangunan atau Hak Pakai dapat dinyatakan sebagai tanah terlantar apabila tanah tersebut dengan sengaja tidak dipergunakan oleh pemegang haknya sesuai dengan keadaannya atau sifat dan tujuan haknya atau tidak dipelihara dengan baik.

Implementasi Peraturan Pemerintah No 11 tahun 2010 telah memberikan gambaran belum optimalnya upaya penertiban tanah terlantar dilakukan sampai mencapai adanya kepastian hukum yaitu adanya tindakan yuridis berupa penetapan adanya tanah terlantar, kemudian itu dipakai sebagai dasar tindakan sebagai pembatalan hak atas tanah. Sehingga status tanah kembali dalam penguasaan negara yang kemudian diserahkan kepada pihak lain untuk diberdayakan.
Berkaitan dengan latar belakang tersebut dan kompleksitas nya permasalahan pertanahan tanah air khususnya di wilayah Bengkulu, maka peneliti bermaksud mengadakan penelitian dengan judul : Analisis Peraturan Kepala Badan Pertanahan Nasional Ri No 4 Tahun 2010 Tentang Tata Cara Penertiban Tanah Terlantar (Studi Kasus Eks. Pabrik Es Dan Gudang Kopi Di Kelurahan Bajak)

\section{A. Rumusan Masalah}

Berdasarkan uraian latar belakang diatas, maka permasalahan yang peneliti coba angkat adalah sebagai berikut : Bagaimana pengaturan Kepala BPN RI No 4 Tahun 2010 dalam memberikan kewenangn kantor pertanahan Kota Bengkulu dalam melakukan penertiban tanah terlantar di bekas Pabrik Es dan Gudang Kopi di Kelurahan Bajak ?

\section{B. Tujuan dan Kegunaan Penelitian}

\section{Tujuan Penelitian}

Berdasarkan rumusan masalah diatas, maka tujuan penelitian ini adalah untuk mengetahui bagaimana peranan kantor pertanahan Kota Bengkulu dalam melakukan penertiban tanah terlantar di bekas Pabrik Es dan Gudang Kopi di Kelurahan Bajak? 
2 Kegunaan Penelitian

Kegunaan penelitian ini nantinya dapat digunakan sebagai data awal bagi pemerintah khususnya kantor pertanahan kota bengkulu dalam menertibkan tanah terlantar dikota Bengkulu.

\section{Sasaran dan Manfaat Penelitian}

\section{Sasaran Penelitian}

Sasaran Penelitian ini adalah Kantor Pertanahan Kota Bengkulu sebagai pengambil kebijakan melakukan penertiban tanah terlantar

\section{Manfaat Penelitian}

\section{a. Secara teoritis}

Hasil penelitian ini diharapkan dapat bermanfaat untuk keperluan yang bersifat teoritis yaitu manfaat diberikan dapat berupa berbagai konsep dalam menertibkan tanah terlantar secara tepat dan benar

\section{b. Secara Praktis}

Manfaat praktis dari penelitian ini dapat berupa (problem Solving) dari permasalahan tanah terlantar, dan manfaat praktis diharapkan juga menjadi bahan bagi pengembangan ilmu pengetahuan khususnya ilmu hukum dan hukum agraria

\section{Metode Penelitian}

\section{Jenis Penelitian}

Jenis penelitian yang digunakan adalah penelitian hukum normatif yang mengkaji hukum tertulis dari berbagai aspek, yaitu aspek teori, sejarah, filosofi, perbandingan, struktur dan komposisi, lingkup dan materi, konsistensi, penjelasan umum, dan pasal demi pasal.

\section{Data Penelitian}

Penelitian ini menggunakan data primer dan data sekunder, yaitu :

\section{a. Data Primer}

Bahan hukum primer adalah bahan-bahan hukum yang mempunyai kekuatan hukum mengikat. adapun bahan hukum primer yang digunakan dalam penelitian ini yaitu : Peraturan Kepala Badan Pertanahan Nasional Republik Indonesia No 4 Tahun 2010 Tentang Tata Cara Penertiban Tanah Terlantar

\section{b. Data Sekunder}

Data sekunder adalah data yang diperoleh dengan mempelajari bahan-bahan pustaka yang berupa 


$$
\begin{aligned}
& \text { peraturan perundang- } \\
& \text { undangan dan literatur- } \\
& \text { literatur lainnya yang } \\
& \text { berhubungan dengan } \\
& \text { permasalahan yang dibahas. } \\
& \text { Data-data tersebut diperoleh } \\
& \text { dari buku-buku kepustakaan, } \\
& \text { browsing internet, dan } \\
& \text { dokumen- } \\
& \text { dokumenlainnya.Dalam hal } \\
& \text { ini penelit imencari buku- } \\
& \text { buku yang dibutuhkan. }
\end{aligned}
$$

\section{Bahan hukum Primer}

Bahan hukum primer
adalah bahan hukum
yang mengikat atau
bahan yang berkaitan
erat
permasalahan
diteliti.

2. Bahan

Hukum

\section{Sekunder}

Bahan hukum yang memberikan penjelasan mengenai bahan-bahan hukum primer yang diperoleh dari studi kepustakaan berupa literature-literatur yang berkaitan dengan permasalahan penelitian. seperti, doktrin, hasil penelitian dan karya ilmiah

\section{Bahan Hukum Tersier}

Bahan hukum yang memberikan petunjuk maupun penjelasan terhadap bahan hukum primer dan sekunder yang berkaitan dengan penelitian ini diataranya adalah surat kabar, internet, kamus Hukum,dan kamus Besar Bahasa Indonesia

\section{Analisis Data}

Data yang telah
dikumpulkan dalm pencarian
data itu disusun dalam satu
sistem (disistematisir),
kemudian data yang telah
tersusun dalam satu sistem itu
dijelaskan dalam satu evalusai,
selanjutnya berdasarkan
penjelasan dan evaluasi dibuat
kesimpulan ${ }^{4}$ Pengolahan data
pada penelitian hukum pada
intinya adalah mencari
kebenaran hukum, kebenaran
hukum adalah kebenaran dalam

4 F Sugeng Istanto, 2007, Penelitian Hukum, CV. Ganda, Yogyakartahal h. 26 
Hendi Sastra Putra:

Analisis Peraturan Kepala Badan Pertanahan Nasional RI 4 Tahun 2010 Tentang Tata Cara Penertiban Tanah Terlantar (Studi Kasus eks. Pabrik Es dan Gudang Kopi di Kelurahan Bajak)

arti suatu kesesuaian dengan

hukum positif dan kebenaran hukum positif.

Kebenaran kualitatif adalah kebenaran dalam arti kesesuaian dengan ukuran yang menetapkan persyaratan kualitas tertentu yang harus dipenuhi hal ini disebabkan karena kebenaran berdasarkan ketentuan hukum positif kebanyakan ditentukan berdasarkan persyaratan kualitas $^{5}$.

Pengambilan kesimpulan dilakukan dengan :

a. Metode Deduktif yaitu dengan cara pengambilan kesimpulan dengan berpijak pada keteranganketerangan yang bersifat umum. Dari keteranganketerangan tersebut ditarik kesimpulan yang bersifat khusus.

b. Metode Induktif yaitu dengan cara pengambilan kesimpulan dengan mendasarkan pada keterangan-keterangan

${ }^{5}$ F Sugeng Istanto, ..h. 60 yang bersifat khusus. Dari keterangan-keterangan yang bersifat khusus tersebut kemudian ditarik kesimpulan yang bersifat umum.

\section{E. Tinjauan Teoritis}

\section{A. Tanah Terlantar}

Tanah terlantar menurut Pasal 1 Angka 6 mengenai tanah terlantar adalah tanah yang sudah diberikan hak oleh negara berupa Hak Milik, Hak Guna Usaha, Hak Guna Bangunan, Hak Pakai, dan Hak Pengelolaan, atau dasar penguasaan atas tanah yang tidak diusahakan, tidak dipergunakan, atau tidak dimanfaatkan sesuai dengan keadaannya atau sifat dan tujuan pemberian hak atau dasar penguasaannya.

Pasal 1 angka 5 Peraturan Pemerintah Republik Indonesia No 36 Tahun 1998 Tentang Penertiban Dan Pendayagunan Tanah Terlantar, memberika pengertian mengenai tanah terlantar. Tanah terlantar adalah tanah yang diterlantarkan oleh pemegang hak atas tanah, pemegang Hak Pengelolaan atau pihak yang telah memperoleh dasar penguasaan atas tanah tetapi belum memperoleh hak atas tanah sesuai 
ketentuan peraturan perundangundangan

Tanah mempunyai fungsi sosial berarti harus ada keseimbangan antara kepentingan individu (pemilik, penguasa, penyewa) dengan kepentingan masyarakat dan negara,dalam pendayagunaan tanah tersebut, dalam hal ini misalnya ${ }^{6}$ :

1) Pemilik tanah harus selalu melakukan pemeliharaanpemeliharaan atas tanah miliknya dan mendayagunakan sedemikian rupa agar tanah berproduksi dengan baik, sehingga hasilnya selain mencukupi kebutuhan sendiri dapat pula dipasarkan, dengan demikian masyarakat dapat turut menikmati hasil olahan tersebut.

2) Pemilik tanah dalam hal mennyewakan tanahnya kepada petani, tidaklah secara mutlak menyerahkan tanggung jawab pemeliharaannya kepada penyewa, melainkan pula harus secara gorong royong antar pemilik dan penyewa, lebihlebih dalam rangka bagi hasil, dimana pemilik misalnya

${ }^{6}$ A.G Kartasapoetra. A G. Kartasapoetra, R.G Kartasapoetra, Hukum Tanah "Jaminan UUPA Bagi Keberhasilan Pendayagunaan Tanah, Agraria, $1991<$ Https://Doi.Org/1>. menyediakan zat-zat penyubur tanaman dan lain-lain yang diperlukan secara adil, karena hasilnya pun untuk kepentingan bersama.

3) Pemerintah telah memberikan/mengatur hak-hak kepada para pemilik tanah, baik untuk mendayagunakan tanah, perlindungan terhadap hak itu, maupun pemberian fasilitasfaslitas bagi kelancaran pendayagunaan tanah tersebut, untuk hal ini pemilik harus mengimbanginya yaitu melakukan pembayaranpembayaran Ireda dan Ipeda, dengan mana pembangunanpembangunan prasarana baik untuk kepentingannya sendiri maupun untuk kepentingan umum dapat dilaksanakan dengan lancar.

4) Hak atas tanah adalah hak yang memberi wewenang kepada pemegang haknya untuk mempergunakan atau mengambil manfaat dari tanah yang di hakinya. Perkataan “mempergunakan" mengandung pengertian bahwa hak atas tanah itu dipergunakan untuk kepentingan mendirikan bangunan, sedangkan perkataan 
Hendi Sastra Putra:

Analisis Peraturan Kepala Badan Pertanahan Nasional RI 4 Tahun 2010 Tentang Tata Cara Penertiban Tanah Terlantar (Studi Kasus eks. Pabrik Es dan Gudang Kopi di Kelurahan Bajak)

"mengambil

manfaat"

mengandung pengertian bahwa

hak atas tanah itu dipergunakan

untuk kepentigan bukan

mendirikan bangunan, misalnya

pertanian,

perikanan,

peternakan, perkebunan ${ }^{7}$.

Sedangkan pranata-pranata yang telah diformalkan dikaji melalui hukum positif dengan berpedoman kepada aturan-aturan yang telah dibuat oleh lembaga Negara/pemerintah. Tetang hak-hak ini sebagian UUPA mengatur tentang hak-hak transaksi ini seperti pada pasal 16, yang akan dikemukakan pada pembahasan ini adalah pasal 16ayat (1) huruf $h$, yaitu " hak-hak lainnya tidak termasuk dalam hak-hak yang sifatnya sementara seperti yang disebutkan pada pasal $53^{8}$

\section{B. Hak Milik}

Menurut Pasal 20 ayat (1) UUPA pengertian hak milik adalah sebagai berikut: hak turun-temurun, terkuat dan terpenuh yang dapat dipunyai orang atas tanah

${ }^{7}$ Urip Santoso, Hukum Agraria Dan HakHak Atas Tanah, 2007.

${ }^{8}$ Imam Mahdi, 'Pengadaan Tanah Melalui Pranata Adat Di Provinsi Bengkulu (Kajian Dalam Hukum Dan Ekonomi)', h, 133-41.
Berkaitan dengan pengertian hak milik atas tanah Pasal 20 UUPA) Notonagoro merinci tentang ciri-ciri hak milik, sebagai berikut :

1. Merupakan hak atas tanah terkuat bahkan menurut Pasal 20 ayat (1) UUPA adalah yang terkuat, artinya mudah dihapus dan mudah dipertahankan terhadap gangguan pihak lain.

2. Merupakan hak turun-temurun dan dapat beralih, artinya dapat dialihkan kepada ahli waris yang berhak.

3. Dapat menjadi hak induk, tetapi tidak dapat berinduk pada hak-hak atas tanah lainnya, berarti hak milik dapat dibebani dengan hakhak atas tanah lainnya, seperti HGB, HGU, HP, hak sewa, hak gadai, hak bagi hasil, dan hak numpang karang.

4. Dapat dijadikan jaminan hutang dengan dibebani hak tanggungan (dahulu hypotheek dan credietverband).

5. Dapat dialihkan, seperti dijual, ditukar dengan benda lain, dihibahkan, dan diberikan dengan wasiat. 
6. Dapat dilepaskan dengan yang punya, sehingga tanahnya menjadi tanah yang dikuasai oleh negara.

7. Dapat diwakafkan.

8. Pemilik mempunyai hak untuk menuntut kembali terhadap orang yang memegang benda tersebut. Penggunaan tanah harus disesuaikan dengan keadaan dan sifat dari haknya, hingga bermanfaat bagi kesejahteraan dan kebahagiaan yang punya tanah maupun bagi masyarakat dan negara. Hal yang prinsip dalam fungsi sosial adalah dalam pelaksanaannya, kepentingan perorangan tidak terdesak sama sekali oleh kepentingan umum.

Kepentingan masyarakat dan perorangan harus saling mengimbangi, sehingga pada gilirannya akan tercapai tujuan pokok UUPA, yaitu kemakmuran, keadilan, dan kebahagiaan bagi seluruh rakyatnya (Pasal 2 ayat (3) UUPA). Amanat UUPA sehubungan dengan makna fungsi sosial, menyebutkan adalah suatu hal yang wajar bahwa tanah itu dipelihara dengan sebaik-baiknya, agar bertambah kesuburannya dan dicegah kerusakannya. Kewajiban untuk memelihara tidak saja dibebankan kepada pemiliknya atau pemegang hak, melainkan menjadi beban setiap orang, badan hukum, atau instansi yang mempunyai hubungan hukum dengan tanah itu, dengan memperhatikan kepentingan pihak ekonomi lemah (Pasal 15 UUPA).

Terjadinya hak milik atas tanah merupakan dasar timbulya hubungan hukum antara subyek dengan tanah sebagai obyek hak. Pada dasarnya hak milik dapat terjadi secara original dan derivatif yang mengandung unsur, ciri, dan sifat masing-masing. Secara original hak milik terjadi berdasarkan hukum adat, sedangkan secara derivatif ditentukan oleh peraturan perundang-undangan.

Dalam ketentuan UUPA, hak milik terjadi karena lima hal .

1. Menurut hukum adat,

2. Penetapan pemerintah,

3. Karena undang-undang,

4. Ketentuan konversi,

5. Karena peningkatan hak.

\section{Pembahasan}

Kewenangan Kantor Pertanahan Kota

Bengkulu Berdasarkan Peraturan

Kepala Badan Pertanahan Nasioan Republik Indonesia Nomor 4 tahun 2010 


\section{Badan Pertanahan Nasional}

membagi 2 kategori untuk tanah terlantar dan teridentifikasi tanah terlantar, seperti yang tecantum pada Pasal 1 angka 5 dan 6 Peraturan Kepala Badan Pertanahan Nasioan Republik Indonesia Nomor 4 tahun $2010^{9}$

Pasal 1 angka 6

"tanah terlantar adalah tanah yang sudah diberikan hak oleh Negara berupa hak milik, hak guna usaha, hak guna bangunan, hak pakai dan hak pengelolaan atau dasar penguasaan tanah yang tidak diusahakan, tidak dipergunakan atau tidak dimanfaatkan sesuai dengan keadaannya atau sifat dan tujuan pemberian hak atau dasar penguasaannya"

Sedangkan pada pasal 1 angka 5

"tanah yang di indikasikan telantar adalah tanah yang diduga tidak diusahakan, tidak dipergunakan atau tidak dimafaatkan sesuai dengan keadaan atu sifat dan tujuan pemberian hak atau dasar pengusaannya belum dilakukan identifikasi dan penelitian"

$$
\text { Dalam menjalankan tugas }
$$

menertibkan tanah telantar kantor pertanahan berpegang teguh dengan aturan yang berlaku yaitu Peraturan Pemerintah No 11 Tahun 2010 tentang Penertiban dan Pendayagunaan Tanah Terlantar ${ }^{10}$ dan juga Peraturan Kepala Badan Pertanahan Nasioan Republik Indonesia Nomor 4

${ }^{9}$ LINI Ratnasari, 'Pelaksanaan Tugas Dan Fungsi Bpn Dalam Penertiban Dan Pendayagunaan Tanah Terlantar Berdasarkan Pp Nomor 11 Tahun 2010 (Studi Di Kantor Bpn Kabupaten Lombok Tengah)', Jurnal Ilmiah, 2010 (2018).

10 Martin B Wicaksana, 'Peraturan Pemerintah No 11 Tahun 2010’, 2005, 2010, 1-12. tahun 2010 tentang Tata cara penertiban Tanah Terlantar ${ }^{11}$.

Kantor pertanahan kota Bengkulu dalam menetapkan tanah terlantar mengacu pada pasal 3 Peraturan Kepala Badan Pertanahan Nasioan Republik Indonesia Nomor 4 tahun 2010 " penertiban tanah terlantar sebagaimana dimaksud dengan dalam pasal 2 dilakukan dengan tahap :

a. Inventarisasi tanah hak atau dasar hak penguasaan atas tanah yang terindikasi terlantar;

b. Identifikasi dan penelitian tanah teridentifikasi terlantar

c. Peringatan terhadap pemegang hak

d. Penetapan tanah terlantar

$$
\text { Selanjutnya tanah yang }
$$
teridentifikasi terlantar di inventarisis sesuai dengan fakta di lapangan hal ini sesuai dengan pasal 4 ayat 2 "informasi tanah teridentifikasi terlantar diperoleh oleh dari hasil pemantauan lapangan oleh kantor Wilayah, kantor Pertanahan, atau dari laporan dinas/instansi lain, laporan tertulis dari masyarakat dan pemegang hak.

Kemudian menurut pasal 6 Inventarisasi tanah terindikasi terlantar dilaksanakan melalui :

11 Republic Of Indonesia Government, 'Peraturan Kepala Badan Pertanahan Nasional Republik Indonesia Nomor 4 Tahun 2010’, 2010. 
a. pengumpulan data mengenai tanah yang terindikasi terlantar meliputi data tekstual dan data spasial:

1. data tekstual meliputi nama dan alamat pemegang hak, nomor, dan tanggal keputusan pemberian hak, nomor, tanggal, dan berakhirnya sertipikat, letak tanah, luas tanah, penggunaan tanah, luas tanah terindikasi terlantar;

1. data spasial merupakan data grafis berupa peta yang dilengkapi dengan koordinat posisi bidang tanah terindikasi terlantar.

b. pengelompokan data tanah yang terindikasi terlantar yang terhimpun sebagaimana pada huruf a dilakukan menurut wilayah kabupaten/kota dan jenis hak/dasar penguasaan dengan format Lampiran 1.

c. pengadministrasian data hasil inventarisasi tanah terindikasi terlantar sebagaimana dimaksud pada huruf a, diselenggarakan secara tertib dalam basis data untuk keperluan pelaporan, bahan analisis, dan penentuan tindakan selanjutnya. Pasal 8 ayat (2) Kegiatan penyiapan data dan informasi sebagaimana dimaksud pada ayat (1) meliputi : a. verifikasi data fisik dan data yuridis meliputi jenis hak dan letak tanah.

b. mengecek buku tanah dan/atau warkah dan dokumen lainnya untuk mengetahui keberadaan pembebanan, termasuk data, rencana, dan tahapan penggunaan dan pemanfaatan tanah pada saat pengajuan hak;

c. meminta keterangan dari pemegang hak dan pihak lain yang terkait, apabila pemegang hak/kuasa/wakil tidak memberikan data dan informasi atau tidak ditempat atau tidak dapat dihubungi, maka identifikasi dan penelitian tetap dilaksanakan dengan cara lain untuk memperoleh data dengan format Lampiran 2;

d. melaksanakan pemeriksaan fisik berupa letak batas, penggunaan dan pemanfaatan tanah dengan menggunakan teknologi yang ada;

e. melaksanakan ploting letak penggunaan dan pemanfaatan tanah pada peta pertanahan berdasarkan hasil pemeriksaan fisik sebagaimana dimaksud pada huruf d;

f. membuat analisis penyebab terjadinya tanah terlantar antara 
Hendi Sastra Putra:

Analisis Peraturan Kepala Badan Pertanahan Nasional RI 4 Tahun 2010 Tentang Tata Cara Penertiban Tanah Terlantar (Studi Kasus eks. Pabrik Es dan Gudang Kopi di Kelurahan Bajak)

lain menyangkut permasalahan-

permasalahan penyebab

terjadinya tanah terlantar,

kesesuaian dengan hak yang

diberikan, dan kesesuaian

dengan tata ruang;

g. menyusun laporan hasil

identifikasi dan penelitian dengan format Lampiran 3.

Setelah identifikasi maka kantor pertanahan akan membentuk suatu panitia sesuai dengan pasal dan pasal 10

Pasal 9

"Setelah data hasil identifikasi dan penelitian sebagaimana dimaksud dalam Pasal 8 dinilai cukup sebagai bahan pengambilan keputusan upaya penertiban, Kepala Kantor Wilayah membentuk Panitia $\mathrm{C}$ yang terdiri dari unsur Kantor Wilayah, Kantor Pertanahan, Pemerintah Daerah, dan instansi yang berkaitan dengan peruntukan tanah yang bersangkutan."

Pasal 10

1) Susunan keanggotaan Panitia C sebagaimana dimaksud dalam Pasal 9 terdiri atas :

a. Ketua : Kepala Kantor Wilayah

b. Sekretaris : Kepala Bidang Pengendalian Pertanahan dan Pemberdayaan Masyarakat, merangkap anggota c. Anggota :

1 Sekretaris

Daerah

Kabupaten/Kota

2 Dinas/Instansi Provinsi yang berkaitan dengan peruntukan Tanahnya

3 Dinas/Instansi

Kabupaten/Kota yang berkaitan dengan peruntukan tanahnya

4 Kepala Kantor Pertanahan

2) Untuk membantu Panitia $\mathrm{C}$ sebagaimana dimaksud pada ayat (1), Kepala Kantor Wilayah membentuk sekretariat.

3) Sekretariat Panitia C membantu menyiapkan semua data yang diperlukan dan membuat resume permasalahan tanah yang terindikasi terlantar dan menjalankan tugas administrasi kesekretariatan.

Panitia $\mathrm{C}$ ini akan bekerja secara professional, setelah teridentifikasi Data luas tanah yang diterlantarkan yang digunakan untuk bahan pembuatan surat peringatan pertama adalah data dari hasil identifikasi dan penelitian Panitia $\mathrm{C}$, sedangkan data untuk surat peringatan kedua dan ketiga adalah data pada akhir peringatan sebelumnya. 
Untuk kriteria tanah terlantar sesuai pasal 17 ayat 2

Kriteria tidak mematuhi sebagaimana dimaksud pada ayat (1) antara lain :

a. tidak menggunakan tanahnya sesuai dengan sifat dan tujuan pemberian haknya;

b. masih ada tanah yang belum diusahakan sesuai dengan Surat Keputusan atau dasar penguasaan tanah;

c. masih ada tanah yang penggunaannya tidak sesuai dengan Surat Keputusan atau dasar penguasaan tanah;

d. tidak ada tindak lanjut penyelesaian pembangunan;

e. penggunaan tanah tidak sesuai dengan Surat Keputusan atau dasar penguasaan tanah; atau

f. belum mengajukan permohonan hak untuk dasar penguasaan tanah.

Dan juga ada pengelompokan tanah terlantar Pasal 20 "Sebagai bahan pertimbangan dalam Penetapan Tanah Terlantar sebagaimana dimaksud dalam Pasal 19 ayat (1), persentase luas tanah yang diterlantarkan dikelompokan menjadi :

a. 100 persen terlantar, b. lebih dari 25 persen sampai dengan kurang dari 100 persen terlantar,

c. kurang dari atau sama dengan 25 persen terlantar.

Untuk sanksi sesuai dengan pasal 23

1) Tanah yang telah ditetapkan sebagai tanah terlantar, dalam jangka waktu paling lama 1 (satu) bulan sejak ditetapkannya keputusan penetapan tanah terlantar, wajib dikosongkan oleh bekas Pemegang Hak atas benda-benda di atasnya dengan beban biaya yang bersangkutan.

2) Apabila bekas Pemegang Hak tidak memenuhi kewajiban sebagaimana dimaksud pada ayat (1), maka benda-benda di atasnya tidak lagi menjadi miliknya dan dikuasai langsung oleh Negara.

Pada awal berdiri sekitar \pm tahun 1977 pabrik es dan gudang kopi merupakan gudang rotan dan pada tahu 1990 memulai dengan mendirikan pabrik es dan gudang kopi. Pada tahun 2000an karena persaingan dengan pabrik es lain, maka pabrik es tersebut tutup, dan juga gudang kopi tidak beroperasi lagi sampai saat ini.

Dengan tidak dimanfaatkan oleh pemilik, dan menjadi terlantar hampir seluruh gudang pabrik es dan gudang kopi rusak parah dan 
Hendi Sastra Putra:

Analisis Peraturan Kepala Badan Pertanahan Nasional RI 4 Tahun 2010 Tentang Tata Cara Penertiban Tanah Terlantar (Studi Kasus eks. Pabrik Es dan Gudang Kopi di Kelurahan Bajak)

ditumbuhi semak belukar. Maka masyarakat setempat menggunakan atau memanfaatkan dengan memelihara kambing, dan juga sebagain dijadikan oleh masyarakat bajak khususnya RT 6 dan RT 5 sebagai lahan untuk perlombaan memperingati 17 agustus.

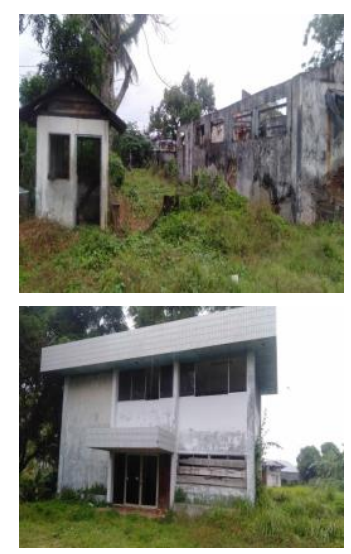

Mantan Ketua RT 5 mengatakan bahwa dengan tidak beroperasi nya lagi gudang kopi dan pabrik es memberikan kesan menyeramkan saat malam hari karena dalam keadaan gelap gulita, dan juga tidak terawatt sehingga semak belukar tumbuh dengan liar, dan juga pernah ada anjing liar melahirkan di gudang tersebut. Kondisi saat ini sesuai dengan apa yang di tampilkan dalam gambar 1 sampai 5.

Penelantaran tanah harus dicegah dan ditertibkan untuk mengurangi atau menghapus dampak negatifnya. Pencegahan, penertiban dan pendayagunaan tanah terlantar merupakan langkah dan prasyarat penting untuk menjalanan program - program pembangunan nasional, terutama di bidang agraria yang telah diamanatkan oleh UUD 1945, UUPA, serta Rencana Pembangunan Jangka Panjang Nasional (RPJPN) ${ }^{12}$.

\section{Penutup}

Dalam melakukan peran sebagai perwakilan kantor pertanaha di kota Bengkulu saat ini sudah bekerja sesuai dengan aturan yang berlaku. Mula dari menerima laporan, mengidentifikasi suatu masalah tanah terlantar, ketika ditemukan teridentikasi tanah terlantar maka akan membentuk suatu panitia. Berdasarkan laporan dari panitia nanti akan memberikan sanksi kepada pemegang hak sesuai dengan pasal 23. Tanah yang telah ditetapkan sebagai tanah terlantar, dalam jangka waktu paling lama 1 (satu) bulan sejak ditetapkannya keputusan penetapan tanah terlantar, wajib dikosongkan oleh bekas Pemegang Hak atas benda-benda di atasnya dengan beban biaya yang bersangkutan.

Apabila bekas Pemegang Hak tidak memenuhi kewajiban sebagaimana dimaksud pada ayat (1), maka benda-benda di atasnya tidak lagi menjadi miliknya dan dikuasai langsung oleh Negara.

12 J. Oliver, 'Konsep Penertiban Dan Pendayagunaan Tanah Terlantar Dalam Perspektif Reforma Agraria', In Hilos Tensados, 2019, I, 1476<Https://Doi.Org/10.1017/CBO9781107415324. 004>. 
Hendak nya masyarakat ikut berperan aktif dalam memberikan laporan baik tanah yang teridentifikasi terlantar atau tanah terlantar.

Kepada pemerintah kota Bengkulu hendaknya bekerja sama dengan baik dan lebih tegas lagi kepada pihak yang melakukan tanah terlantar.

\section{Pustaka Acuan}

G. Kartasapoetra, R.G Kartasapoetra, A.G Kartasapoetra. A, Hukum Tanah "Jaminan UUPA Bagi Keberhasilan Pendayagunaan Tanah, Agraria, 1991 $<$ https://doi.org/1>

Government, Republic of Indonesia, 'Peraturan Kepala Badan Pertanahan Nasional Republik Indonesia Nomor 4 Tahun 2010', 2010

Lini Ratnasari, 'Pelaksanaan Tugas Dan Fungsi Bpn Dalam Penertiban Dan Pendayagunaan Tanah Terlantar Berdasarkan Pp Nomor 11 Tahun 2010 (Studi Di Kantor Bpn Kabupaten Lombok Tengah)', Jurnal Ilmiah, 2010 (2018)

Mahdi, Imam, 'Pengadaan Tanah Melalui Pranata Adat Di Provinsi Bengkulu (Kajian Dalam Hukum Dan Ekonomi)', II, 133-41

Oliver, J., 'Konsep Penertiban Dan Pendayagunaan Tanah Terlantar Dalam Perspektif Reforma Agraria', in Hilos Tensados, 2019, I, 1-476 <https://doi.org/10.1017/CBO9781107 415324.004>

Sastra Putra, Hendi, and Pareke. J.t, Peranan Pemerintah Kabupaten Bengkulu Utara Dalam Penertiban Tanah Terlantar Hak Guna Usaha, ed. 
by Mikho Ardinata, Hukum Agraria

(Jakarta: zara Abadi, 2020)

Urip Santoso, Hukum Agraria Dan Hak-

Hak Atas Tanah, 2007

Wicaksana, Martin B, 'Peraturan

Pemerintah No 11 Tahun 2010', 2005,

2010, 1-12

Yunior, Lianton Vicco, 'Wewenang

Pemerintah Dalam Penentuan Kriteria

Tanah Terlantar', Jurist-Diction, 2.6

(2019), 2175-98 